\title{
Pain neuroscience education for patients with musculoskeletal pain
}

\section{Educação em neurociência da dor para pacientes com dor musculoesquelética}

DOI 10.5935/2595-0118.20200018

Dear editor,

The International Association for the Study of Pain (IASP) created the Special Interest Group (2018-2020) on Pain Education. The group aims to "promote pain education to health professionals, patients, communities, \& policymakers". Pain neuroscience education (PNE) is one approach of pain education that addresses patient misconceptions regarding the physiology of pain and helps to change their maladaptive beliefs and behavior. PNE is a strategy that incorporates the biopsychosocial model and intends to provide knowledge concerning the neurophysiological, neurobiological, and physical components involving pain experien$\mathrm{ce}^{1}$. Systematic reviews demonstrated the effectiveness of PNE in treating patients with chronic musculoskeletal pain ${ }^{2,3}$. Health professionals can modify the concepts patients have about their pain. Likewise, the beliefs that health professionals have about pain can interfere with patients' beliefs. Recent studies have shown low levels of pain knowledge by health professionals, physical therapy students, and patients. Thus, assessing the knowledge about the neurophysiology of pain is essential to understand and modify thoughts regarding the origin of pain.

Knowledge about pain neuroscience is fundamental to conduct appropriate patient management. A systematic review of the literature showed that strong evidence supports the use of PNE for musculoskeletal disorders ${ }^{3}$. For instance, patients with chronic fatigue syndrome could increase their understanding of the neurophysiology of pain after pain physiology education; Besides, PNE resulted in less worrying in the short term, and long-term improvements in vitality, physical functioning, mental health, and general health perceptions in patients with fibromyalgia. Moreover, patients with lumbar radiculopathy who received a single PNE session before lumbar surgery showed a significant reduction in health care costs three years after lumbar surgery ${ }^{3}$. Despite the available evidence supporting the relevance of health professionals to address the different aspects of the pain experience, they considered a straightforward relationship between pain and harm, which may be related to the lack of specific pain courses in the Brazilian health education programs as Physical Therapy schools ${ }^{4}$.

Most of the patients do not understand the mechanisms of pain and, therefore, believe that the pain is always associated with tissue damage. Brazilian patients with musculoskeletal pain also presented a low level of neurophysiological pain knowledge, re- gardless of the pain predominance based on its mechanism ${ }^{5}$. In conclusion, clinicians should use strategies to improve the level of neurophysiological pain knowledge, which assists the pain management of patients with musculoskeletal pain. Likewise, PNE should be incorporated into the undergraduate curricula of health professionals to enhance the understanding of pain for clinicians and patients.

Sincerely,

$$
\begin{array}{r}
\text { Juliana Valentim Bittencourt } \\
\text { Centro Universitário Augusto Motta, } \\
\text { Fisioterapia, Rio de Janeiro, RJ, Brasil. } \\
\text { (D) https://orcid.org/0000-0001-9522-8523 } \\
\text { Letícia Amaral Corrêa } \\
\text { Centro Universitário Augusto Motta, } \\
\text { Fisioterapia, Rio de Janeiro, RJ, Brasil. } \\
\text { (D) https://orcid.org/0000-0002-8188-7111 } \\
\text { Felipe José Jandre dos Reis } \\
\text { Instituto Federal de Educaçáo, Ciência e Tecnologia do } \\
\text { Rio de Janeiro, Fisioterapia, Rio de Janeiro RJ, Brasil. } \\
\text { (D) https://orcid.org/0000-0002-9471-1174 } \\
\text { Leandro Alberto Calazans Nogueira } \\
\text { Centro Universitário Augusto Motta, } \\
\text { Fisioterapia, Rio de Janeiro, RJ, Brasil. } \\
\text { Instituto Federal de Educaçấ, Ciência e Tecnologia do Rio } \\
\text { de Janeiro, Fisioterapia, Rio de Janeiro, RJ, Brasil. } \\
\text { (D) https://orcid.org/0000-0002-0177-9816 } \\
\text { E-mail: juliana.valentimfisioterapia@gmail.com }
\end{array}
$$

\section{REFERENCES}

1. Moseley GL, Butler DS. Fifteen years of explaining pain: the past, present, and future. J Pain. 2015;16(9):807-13

2. Louw A, Diener I, Butler DS, Puentedura EJ. The effect of neuroscience education on pain, disability, anxiety, and stress in chronic musculoskeletal pain. Arch Phys Med Rehabil. 2011;92(12):2041-56

3. Louw A, Zimney K, Puentedura EJ, Diener I. The efficacy of pain neuroscience education on musculoskeletal pain: a systematic review of the literature. Physiother Theory Pract. 2016;32(5):332-55.

4. Venturine JS, Pires GMT, Pereira ML, Monteiro MGM, Meziat-Filho N, Nogueira LC, et al. Overview of curricula about pain in physical therapist education programs in Brazil: a faculty survey. Phys Ther. 2018;98(11):918-24.

5. Ferreira PS, Corrêa LA, Bittencourt JV, Reis FJJ, Meziat-Filho N, Nogueira LAC Patients with chronic musculoskeletal pain present low level of the knowledge about the neurophysiology of pain. Eur J Physiother. 2019;0(0):1-6. DOI; 10.1080/21679169.2019.1676307.

(C) Sociedade Brasileira para o Estudo da Dor 